\section{Search for} Handwashing Studies

\section{Dear Colleagues:}

We are conducting a historical review of studies that evaluate the influence of handwashing on infections. We are seeking in formation about any such studies, published or unpublished, that were conducted in the nineteenth and twentieth centuries. If you have information on such studies, we would be most appreciative if you could share it with us. Please address correspondence to Dr. Elaine Larson, The Johns Hopkins University School of Nursing, Houck $386,600 \mathrm{~N}$. Wolfe Street, Baltimore, MD 21205, or call collect to 301-955-7484. Thank you.

Elaine Larson, PhD, RN, FAAN Nutting Chair in Clinical Nursing

\section{Recreational Infections}

\section{To the Editor:}

We much appreciated the article "Infections Related to Summer Recreational Activities" by Beverly J. Gray and Charles E. Haley. ${ }^{1}$ Nevertheless, their exhaustive list in Table 1 lacked a relevant cause of this kind of infection, ie, leptospirosis.

We propose its inclusion in that table, with the following statements: infection: Leptospirosis; infectious agent: Leptospira interrogans; source: water, soil; epidemiology ${ }^{2}$ : swimming, fishing, drinking unpurified water; major clinical features ${ }^{3}$ : fever, headache; diagnostic tests ${ }^{4}$ : serologic tests.

\section{REFERENCES}

1. Gray B], Haley CE: Infections related to summer recreational activities. Infect Control 1985 ; 6(12):498-500.

2. Diesch SL, Ellinghausen HC: Leptospirosis, in Hubber WT, McCullogh WF, Schnurrenberger PR (eds): Diseases Transmitted from Animals to Men, ed 6. Springfield, CC Thomas, 1975, pp 436-462.

3. Heath $\mathrm{CW} J \mathrm{r}$, Alexander $\mathrm{AD}$, Galton MD: Leptospirosis in the United States. Analysis of 483 cases in man, 1949-1961. N Engl J Med 1965; 273:915-922.

4. Alexander AD: Leptospira, in Lennette EH, Balows A, Hauser WJ Jr, et al (eds): Manual of Clinical Microbiology, Washington, American Society for Microbiology, 1985, pp 473-478.

Claudio Maffei, MD Francesco Di Stanislao, MD Institute of Hygiene University of Ancona Medical School Ancona, Italy

Dr. Charles Craig responds to Drs. Maffei and Di Stanislao.

Drs. Maffei and Di Stanislao have correctly suggested that summer recreational activities can expose individuals to infection with leptospires. The annual incidence of leptospires is relatively small, about 75 cases being reported annually to the Centers for Disease Control. It is suspected by some that the disease is significantly underreported, and that most cases are passed off as summer "flu" with fever, headache, muscle aching, and occasionally abdominal pain, nausea, and vomiting. Humans, when they acquire leptospires, represent a dead end for the disease, person-to-person infection being exceedingly rare.

However, the organism can persist in nature, almost perpetually. Wild animals are an important reservoir and provide a source for infection of domestic animals, rather than humans. The organism is excreted in large concentrations in the urine and may subsequently contaminate water and soil.

Maffei and Di Stanislao comment that the list originally published in Infection Control was "exhaustive," but I would add that the list of diseases to which travelers may be exposed is also "exhausting." Indeed, if we spend too much time making preparations for all the potential diseases we might acquire, we may never get beyond the front door next summer.

\section{REFERENCES}

1. Farrar WE: Leptospira species, in Mandell $\mathrm{GH}$, Douglas RG Jr, Bennett JE (eds): Principles and Practice of Infectious Diseases. New York, John Wiley \& Sons, 1979, pp 1844-1849.

2. Gray BJ, Haley CE: Infections related to summer recreational activities. Infect Control 1985 ; $6(12): 498-500$.

Charles P. Craig, MD Chairman, Department of Medicine Mt. Sinai-Daroff Division Albert Einstein Medical Center Philadelphia, Pennsylvania

\section{Protective Precautions for the Patient with AIDS}

\section{To the Editor:}

The increasing number of persons with Acquired Immune Deficiency Syndrome (AIDS), with their need for frequent and prolonged hospitalization, may create a problem of bed availability for hospitals. Patients with AIDS are often placed in a private continued on page 92 